\title{
Habitat Suitability Assessment of Wintering Herbivorous Anseriformes in Poyang Lake, China
}

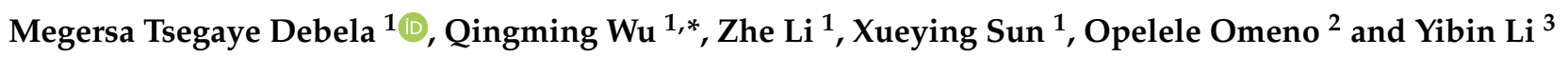 \\ 1 College of Wildlife and Protected Areas, Northeast Forestry University, Harbin 150040, China; \\ megtsegaye@gmail.com (M.T.D.); lizhe@nefu.edu.cn (Z.L.); sxytuvwz@nefu.edu.cn (X.S.) \\ 2 School of Forestry, Northeast Forestry University, Harbin 150040, China; michel.opelele@gmail.com \\ 3 Department of Research and Monitoring, Eco-Bridge Continental, Beijing 100080, China; yibinn.li@gmail.com \\ * Correspondence: qingmingwu@nefu.edu.cn; Tel.: +86-156-6352-6790
}

Citation: Debela, M.T.; Wu, Q.; Li, Z.; Sun, X.; Omeno, O.; Li, Y. Habitat Suitability Assessment of Wintering Herbivorous Anseriformes in Poyang Lake, China. Diversity 2021, 13, 171. https://doi.org/10.3390/d13040171

Academic Editor: Luc Legal

Received: 11 March 2021

Accepted: 11 April 2021

Published: 16 April 2021

Publisher's Note: MDPI stays neutral with regard to jurisdictional claims in published maps and institutional affiliations.

Copyright: (c) 2021 by the authors. Licensee MDPI, Basel, Switzerland. This article is an open access article distributed under the terms and conditions of the Creative Commons Attribution (CC BY) license (https:/ / creativecommons.org/licenses/by/ $4.0 /)$.

\begin{abstract}
To design a good conservation strategy for herbivorous Anseriformes wintering in Poyang Lake, knowledge of habitat suitability is essential. Therefore, this study aimed to assess the habitat suitability of herbivorous Anseriformes of China's Poyang Lake. Landsat images with a resolution of $30 \mathrm{~m}$ downloaded from the United States Geological Survey, and other ancillary data were used. The ENVI 5.3 software and ArcGIS 10.2 software were used for preprocessing, classifying the satellite image, and mapping habitat suitability. The study reveals that land cover types were divided into vegetation, mudflats, water, and sand. Similarly, the study area's habitats were also divided into unsuitable, fair, good, and best grades. However, the distribution of the habitat suitability for each grade reveals significant spatial variations. For instance, vegetation indicated the areas with the best habitat grade, followed by mudflats, and these areas cover $(47.93 \%, 2015$ and $55.78 \%, 2019)$ the majority of the study area. The unsuitable grades cover the smallest areas $(0.48 \%)$ of the lake. Similarly, this study results showed a slight change in habitat suitability areas. Therefore, this study highlighted that Poyang Lake has valuable importance for the conservation of herbivorous Anseriformes. Extending the years of study and including some ecological variables from different stopovers could improve the results.
\end{abstract}

Keywords: geese; Anseriformes; habitat suitability; AHP priority calculator; Poyang lake

\section{Introduction}

Variability in topography and temperature is recognized as the most significant common predictors of bird species richness [1,2]. Heterogeneity of an environment (spatial variation in habitat and local climate) can impact species distribution [3]. The seasonal variation of rainfall and seasonal variation in the accessibility of food resources results in regular variations in the abundance of bird species of particular areas [4,5]. Changes in species richness and composition can also affect the community's functional diversity [6] and changes ecosystem services, which in turn affects humans [7]. Irrespective of their importance, global waterbird populations are decreasing [8]. Natural wetlands loss and degradation are threatening flora and fauna dependent on wetlands. For instance, waterbirds are one of the most sensitive and vulnerable forms of wildlife $[9,10]$. The growth in humans' land-uses reduces habitat availability at breeding and wintering sites [11-13]. Types, sizes, and quantities of available food within wetlands also affect avifauna [14].

Human activities are known to affect waterbirds $[15,16]$ by decreasing their foraging success [10,17], reducing breeding success [18], modifying distribution [19], decreasing species richness [20], and also changing community composition [21,22]. Waterbird habitat damage can result in a decline in waterbird numbers $[23,24]$ or cause waterbirds to move to nearby suitable habitats [25].

All species, including waterbird species, have specific optimum habitat requirements, called habitat factors. These habitat factors regulate the habitat suitability of waterbirds. 
This habitat suitability can be measured by a habitat suitability index (hereafter denoted as HSI). HSI is a variable describing the habitat's priority regarding the species' (or group of species) under consideration [26,27]. HSI is a unitless model that can transform existing knowledge of a species' habitat necessities into standard, quantitative measures of habitat quality. HSI ranges between 0 to 1 , which means that the worst criterion score has a standardized value of 0 , whereas the best has a standardized value of 1 [27-29]. Scholars have developed several methods to assess habitat suitability of wildlife, including maximum entropy models (Maxent) [30], generalized linear models [31], ecological niche variable analysis [32,33], resource-based models [34], the hydrodynamic model, and the vegetation growth threshold [35] and habitat suitability index [36]. These models determine terrain morphology, land cover, meteorological conditions, and distribution of anthropogenic activities that significantly influence the presence, abundance, and distribution of species [31].

Habitat suitability is also a crucial and sensitive index explaining local habitat use [37]. It could have a wide variety of applications in managing biodiversity of species and conservation planning design [38]. Despite improving the ecological environment and biodiversity conservation, most traditional suitability models have focused on the occurrence and have provided relatively qualitative information on species' habitat suitability [39]. Qualitative information relies upon an individual's skills and imageries, so it might not provide accurate information. In contrast, the quantitative analysis provides relatively precise data. Therefore, recently geographic information systems (GIS) and remote sensing (RS) have been broadly used for the quantitative assessments of waterbird habitats [40].

Remote sensing data can help to examine habitat changes which either caused naturally or by anthropologic activities $[40,41]$. For example, the remote sensing data such as the normalized difference vegetation index (NDVI) as a proxy for ecosystem greenness [42] (food abundance), satellite-based slope data indicating shelter condition [31] affecting habitat suitability and density of settlements [43] representing a direct impact of human disturbance on water bird habitats. They have been used extensively as predictors of waterbird's habitat characteristics. Hence, remote sensing is favored for assessing waterbird habitats' suitability.

East Asia's largest freshwater lake [44] has global importance for conserving migratory waterbirds of the East Asia-Australasian Flyway [45,46], and is called Poyang Lake. It is known to have large seasonal water level fluctuations [47-49] and regional landscape changes [50]. In Poyang Lake, three months, namely June, July, and August, are the months with the highest water level while the lowest water levels are seen in January, February, and December [51-53] (Figure S1, when the NDVI value is the lowest). The natural hydrological changes, typically inundations and drying, manage the biodiversity distribution and abundance of an organism and ecological processes in freshwater ecosystems [54,55].

Bird species or groups of bird species' habitat preference can differ significantly over various factors, including food availability, hydrological conditions, and vegetation distribution [56]. Knowledge of waterbirds' habitat requirements [57,58] is crucial to assess their habitat suitability effectively. As a result, previous studies consider several factors while determining species' or groups' of species habitat suitability $[38,59,60]$. However, assessing waterbird habitat suitability by considering several factors has yet to be further explored in Poyang Lake. Therefore, the objective of this study was to quantitatively assess the current habitat suitability of herbivorous Anseriformes (henceforth Anseriformes, the highest proportion of waterbirds in Poyang Lake) $[53,61]$ by employing GIS and remote sensing (RS) tools while considering several factors. The results of this study will help to protect the herbivorous Anseriformes' habitats and may assist as a tool for waterbird conservation of the study area. 


\section{Materials and Methods}

\subsection{Study Area}

Poyang Lake $\left(28^{\circ} 24^{\prime}-29^{\circ} 46^{\prime} \mathrm{N}\right.$ and $\left.115^{\circ} 49^{\prime}-116^{\circ} 46^{\prime} \mathrm{E}\right)$, the study area, is one of the natural reserves listed in the internationally important wetland list in China, and the most prominent waterfowl overwintering place in East Asia. In the same way, it is the largest freshwater lake in China, located at the south bank of Changjiang in Jiangxi province (Figure 1), covering an area of around $1000 \mathrm{~km}^{2}-4000 \mathrm{~km}^{2}$ [44]. Mudflats and wet meadows are the dominant habitats in the dry season, with a less than $1000 \mathrm{~km}^{2}$ surface area covered with water $[53,62]$.
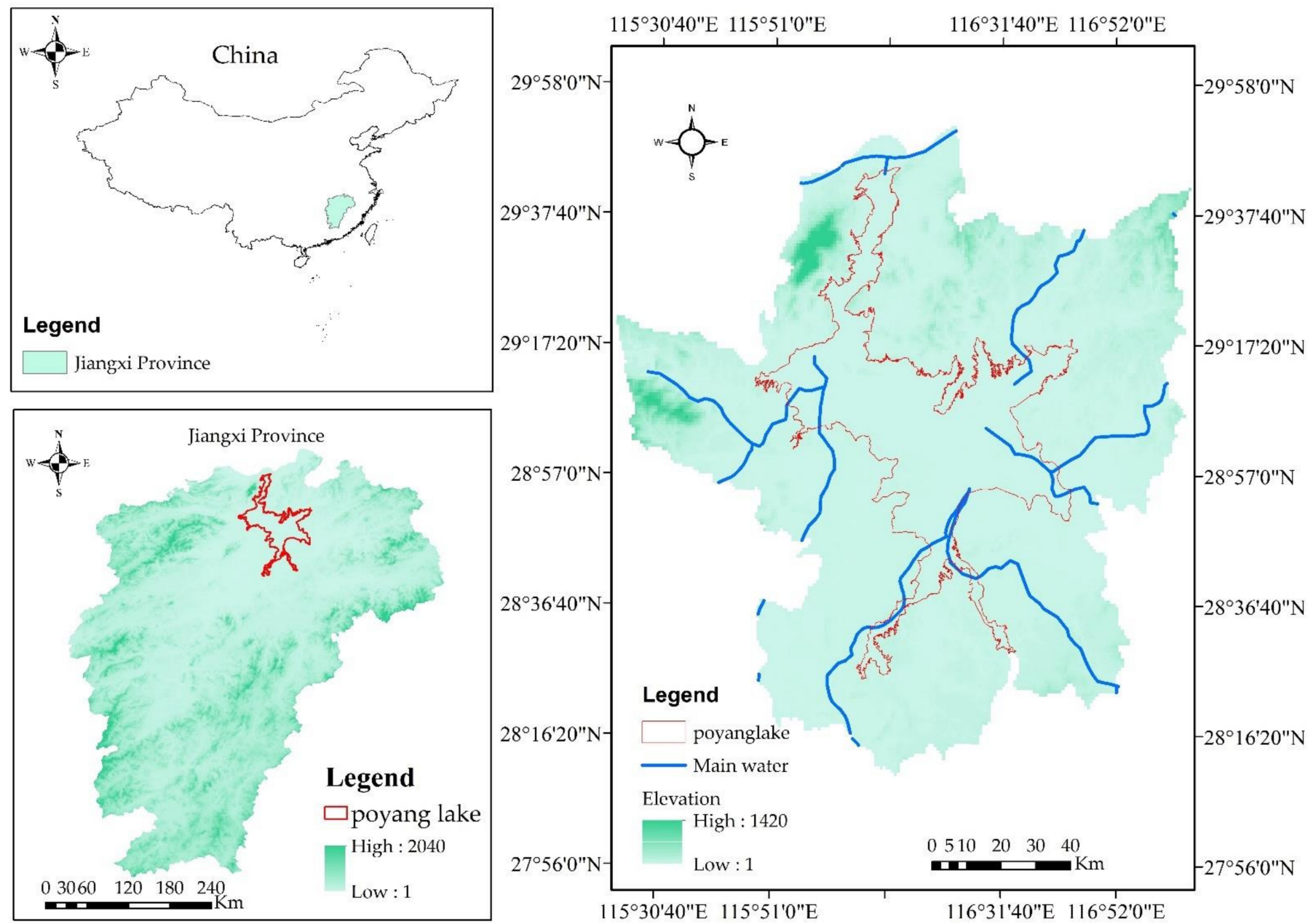

Figure 1. Location of the study area: Poyang Lake, Jiangxi Province, China.

Poyang Lake has a humid subtropical climate with an annual average temperature of 16.7-17.7 ${ }^{\circ} \mathrm{C}$ [63] and average annual precipitation of 1400-1900 $\mathrm{mm}$ [63]. The dominant vegetation types in Poyang lake are Carex spp., Potamogeton spp., and Polygonum spp. (Table S1) [64]. These vegetation types are the essential food source of herbivorous waterbirds wintering in Poyang Lake [65], and its growth process is vulnerable to hydrological fluctuations [66,67]. In winter, Poyang Lake supports more than 400,000 waterbirds on average [45]. Geese are the dominant herbivorous species in Poyang Lake [61,68], namely, the Swan Goose and Lesser White-fronted Goose (Vulnerable), Bean Goose, Greater Whitefronted Goose, and Greylag Goose (Least Concern). The wintering waterbirds' arrival time and leaving time at Poyang Lake mostly depend on the water level. Most wintering waterbirds arrive at Poyang Lake when the water level starts decreasing (in late October) and leave when the water level starts rising (in March). The vegetation index of Poyang 
lake, which could reflect the food abundance of herbivore birds, fluctuates periodically (Figure S1).

\subsection{Methods}

In this study, GIS software and Remote sensing data were employed to assess the herbivorous Anseriformes' habitat suitability. The main environmental indicators that had a controlling effect on the living condition herbivorous Anseriformes' in Poyang Lake were identified based on previous studies [45,61]. Accordingly, four indicators: Landcover types, water abundance, food availability, and human disturbances, were identified to assess herbivorous Anseriformes' habitat suitability.

Two geometrically corrected Level 1T (L1T) scenes of Landsat image (cloud-free operational land image data, OLI images (Worldwide reference system (WRS) path 121, row 40, acquisition date: 22 December 2015-23 February 2019) with the resolution of $30 \mathrm{~m}$ ) downloaded from USGS (http: / / glovis.usgs.gov /, accessed on 22 December 2015-23 February 2019) (Table S2). Similarly, Digital Elevation Model was obtained from USGS and other ancillary data (roads data) extracted for the study area.

The land cover data which reflect the safety of shelter, were extracted from Landsat 8 image bands. Before Landsat image classification, Fast Line-of-sight Atmospheric Analysis of Spectral Hypercubes module (FLAASH) [69] was used to calibrate and remove atmospheric and light factor effects from the objects' reflectance of the image, which can enhance image brightness and facilitate the classification process. A frequently used supervised classification (Maximum Likelihood) method [70] was performed to classify Landsat images in ENVI software. The producer, user, overall accuracy, and Kappa coefficient results were used to evaluate the classification results [71,72]. Finally, the output landcover classification accuracy was assessed using relevant field data and Google Earth's high spatial resolution images.

The normalized difference moisture index (NDMI) values which reflect the abundance of water, were calculated from Landsat 8 bands using the formula, NDMI $=(\mathrm{NIR}-$ $\mathrm{MIR}) /(\mathrm{NIR}+\mathrm{MIR})$, where Band 5 is the near infrared band (NIR), and Band 6 is a middle infra-red band (MIR) [73]. Similarly, the normalized difference vegetation index (NDVI) used to evaluate the food abundance for wintering Anseriformes were also obtained from Landsat 8 bands by using the formula, NDVI $=(\mathrm{NIR}-\mathrm{R}) /(\mathrm{NIR}+\mathrm{R})$, where Band 4 is the Red and Band 5 in the near infra-red band [40]. The slope of the study area that reflects shelter safety was calculated from the Digital Elevation Model (DEM). All the abovecalculated data was processed on the Google Earth Engine (GEE) cloud platform [74].

Obviously, all the criteria (indicators) might not have the same importance. Therefore, all the identified indicators were compared with each other according to experts' advice and assign priority (relative importance) weight by applying the analytic hierarchy process (Hereafter called AHP) methods [75-77]. APH was conducted by an AHP priority calculator [78] and Excel.

The step followed in this study is shown in Figure 2. Herbivorous Anseriformes location collected in our previous study [61] was used to assess habitat suitability assessment accuracy.

MOLUSCE (Methods of Land Use Change Evaluation) [79] of QGIS software 2.01 was used to calculate the suitable herbivorous Anseriformes' habitats suitability change. 


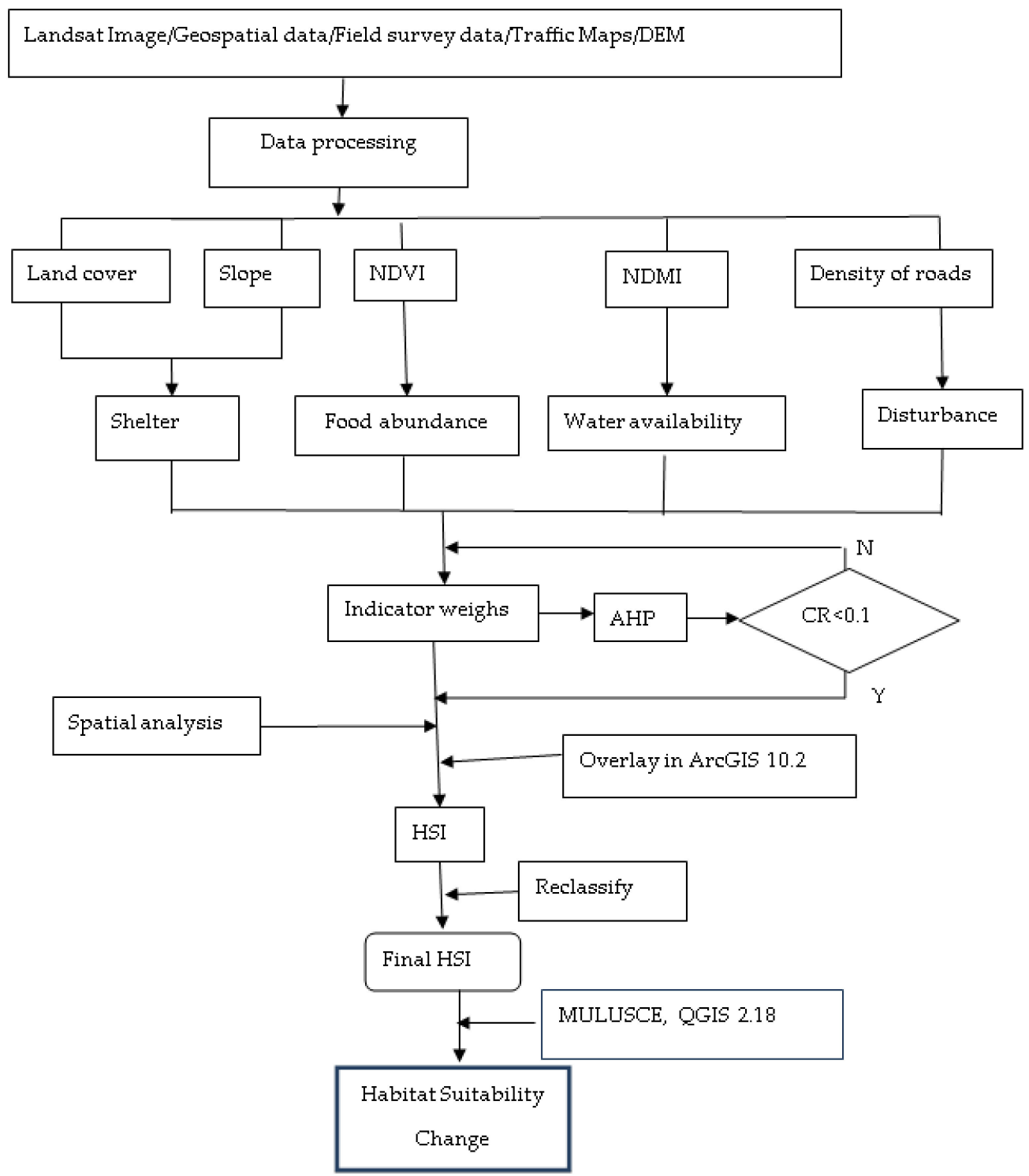

Figure 2. Flowchart of habitat suitability assessment of the herbivorous Anseriformes in Poyang Lake.

\section{Results}

This study assessed the habitat suitability of herbivorous Anseriformes in Poyang lake. To achieve the desired goals of this study, first, the factors that are supposed to have a controlling effect on herbivorous Anseriformes' life were identified. Second, the relative importance (weight) for all identified indicators were assigned using the AHP approach. Finally, depending on the identified indicators, the study area habitat was categorized into four grades (Figures 3-6). The detailed results of the determining factors (Land cover, NDVI, NDMI and, slope) and the AHP used to assess the final habitat suitability of herbivorous Anseriformes of Poyang Lake were explained as follows. 

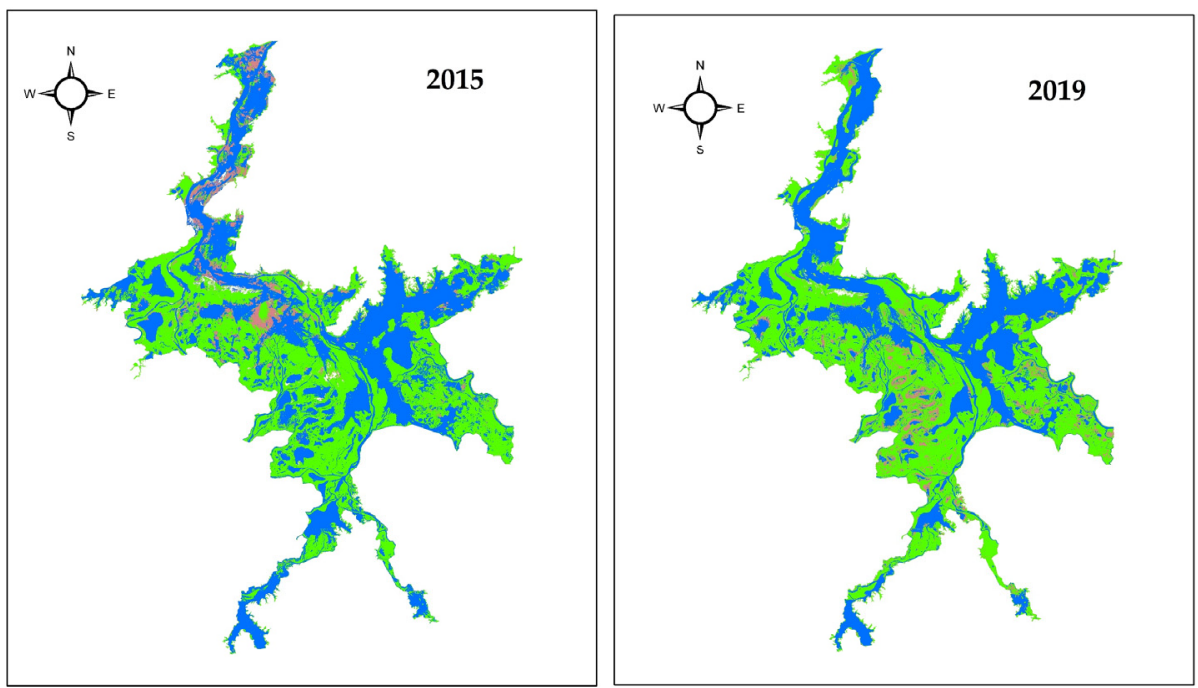

Land cover types

$\neg$ Sands $\square$ Waterbodies $\square$ Mudflats $\square$ Vegetations

Figure 3. Land cover spatial distribution for the winter seasons of 2015 and 2019.
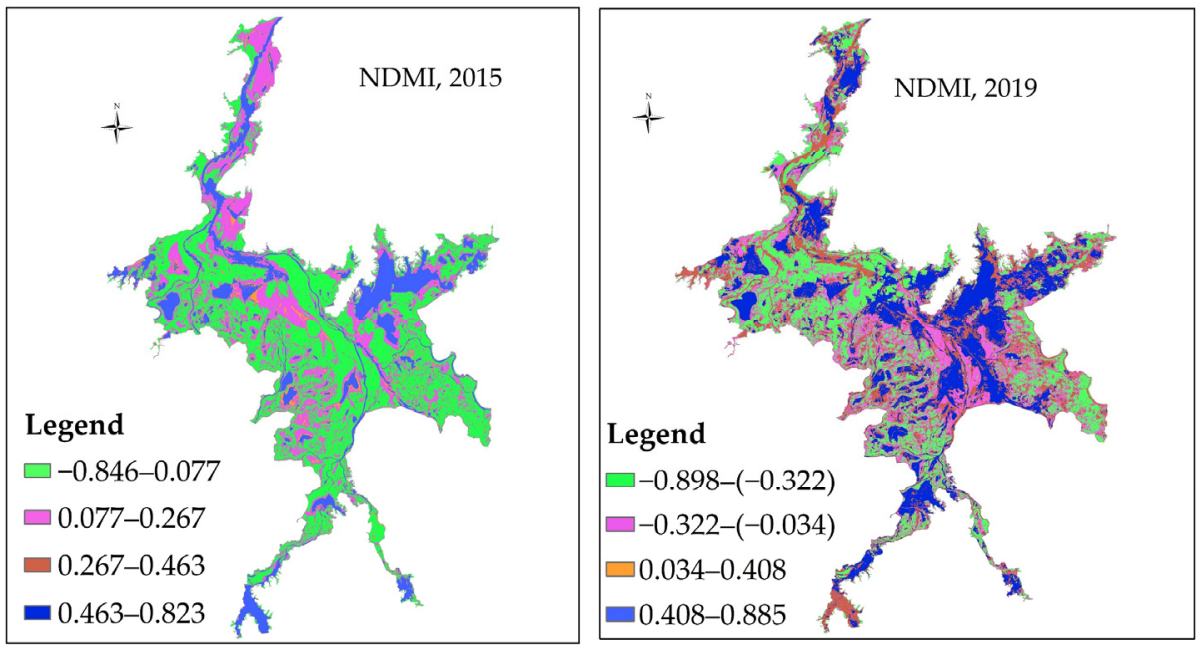

Figure 4. NDMI spatial distribution for the winter season of 2015 and 2019.
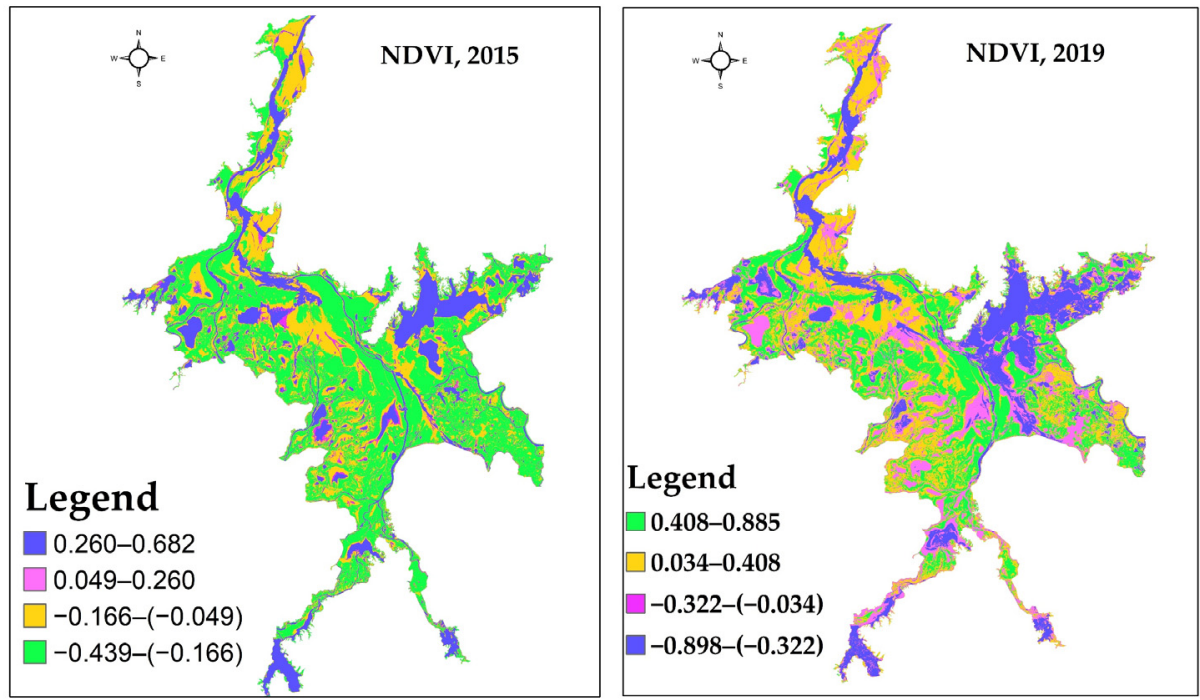

Figure 5. NDVI spatial distribution for the winter season of 2015 and 2019. 

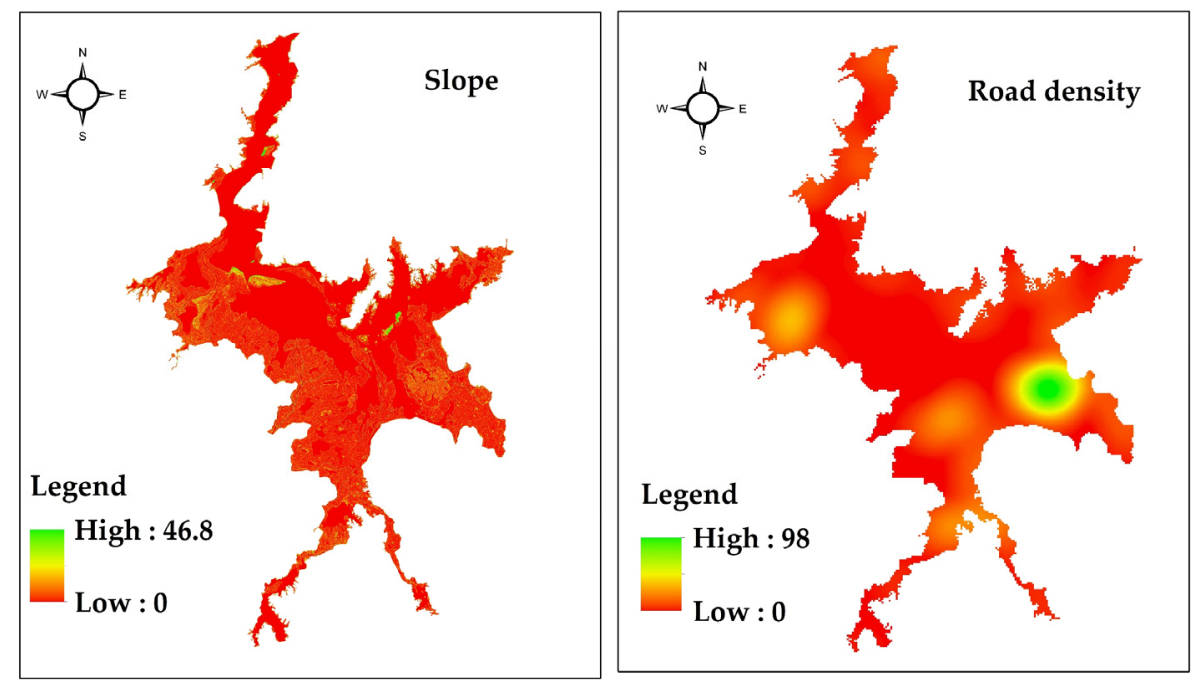

Figure 6. Slope and density of roads spatial distribution in the Poyang Lake.

\subsection{Land Cover Extraction}

Land cover data of the study area for the winter seasons of 2015 and 2019 were obtained by processing and interpreting Landsat 8 images and are presented in Figure 3 . From Landsat 8, four major cover types were identified in Poyang Lake during the study periods, viz. the vegetation, waterbody, mudflat, and sand, and the four types' detailed functions are listed in Dronva's studies [53]. The output landcover classification accuracy assessment shows that the overall accuracy of land cover classification of 2015 and 2019 in this study reaches $96.27 \%$ and $97.58 \%$, and the Kappa values are 93.31 and $96 \%$, respectively (Tables 1 and 2), which is satisfactorily acceptable for the research needs (Above $85 \%$ ).

Table 1. Land cover accuracy of classification results in 2015.

\begin{tabular}{ccc}
\hline Land Use/Land Cover & Producer's Accuracy (\%) & User's Accuracy (\%) \\
\hline Water & 98.72 & 99.20 \\
Vegetation & 90.57 & 98.73 \\
Sand & 98.74 & 99.42 \\
Mudflats & 98.14 & 75.57 \\
Overall Accuracy & & \\
Kappa Coefficient & \multicolumn{3}{|}{} \\
\hline
\end{tabular}

Table 2. Land cover accuracy of classification results in 2019.

\begin{tabular}{ccc}
\hline Land Use/Land Cover & Producer's Accuracy (\%) & User's Accuracy (\%) \\
\hline Water & 96.15 & 99.80 \\
Vegetation & 99.26 & 99.67 \\
Sands & 100.00 & 15.56 \\
Mudflat & 98.14 & 75.57 \\
Overall Accuracy & & \\
Kappa Coefficient & \multicolumn{3}{|}{} \\
\hline
\end{tabular}

In the scenes, vegetation was the dominant cover type, followed by water bodies (Figure 3).

\subsection{Analytic Hierarchy Process (AHP) Approach}

Pair-Wise Comparisons Criteria

In this study, weights for the five indicators obtained were NDVI-0.37, Land cover0.36, NDMI-0.13, Slope—0.07, and disturbance (road density) - 0.07 (Table S3). 


\subsection{Habitat Suitability Index Calculating and Reclassifying}

The weights obtained from the AHP for each indicator were used in the spatial analyst tools of ArcMap 10.2 to arrive at a final suitability map. The map was divided into four natural classes of suitability levels of herbivorous Anseriformes' habitats (Figure 6). A geospatial overlay tool of ArcGIS was used to calculate HSI, which was a linear function $[77,80]$ of indictors as follows:

$$
\text { Habitat Suitability Index (HIS) }=\sum_{i=1}^{n} \text { wifi }
$$

where $w i$ and $f i$ are the normalized weight, such that $\Sigma w i=1$ and value of $i$ indicators, respectively; $n=5$ (in this study).

We assessed the Herbivorous Anseriformes habitat suitability using the land cover types NDVI, NDMI, and slope data layers by the ArcGIS 10.2 software tool. The final suitability map (Figure 7) reveals that the study area was divided into poor (unsuitable), fair, good, and best (suitable) grades, which show a significant spatial variation in their distribution across the study area (Table 3).
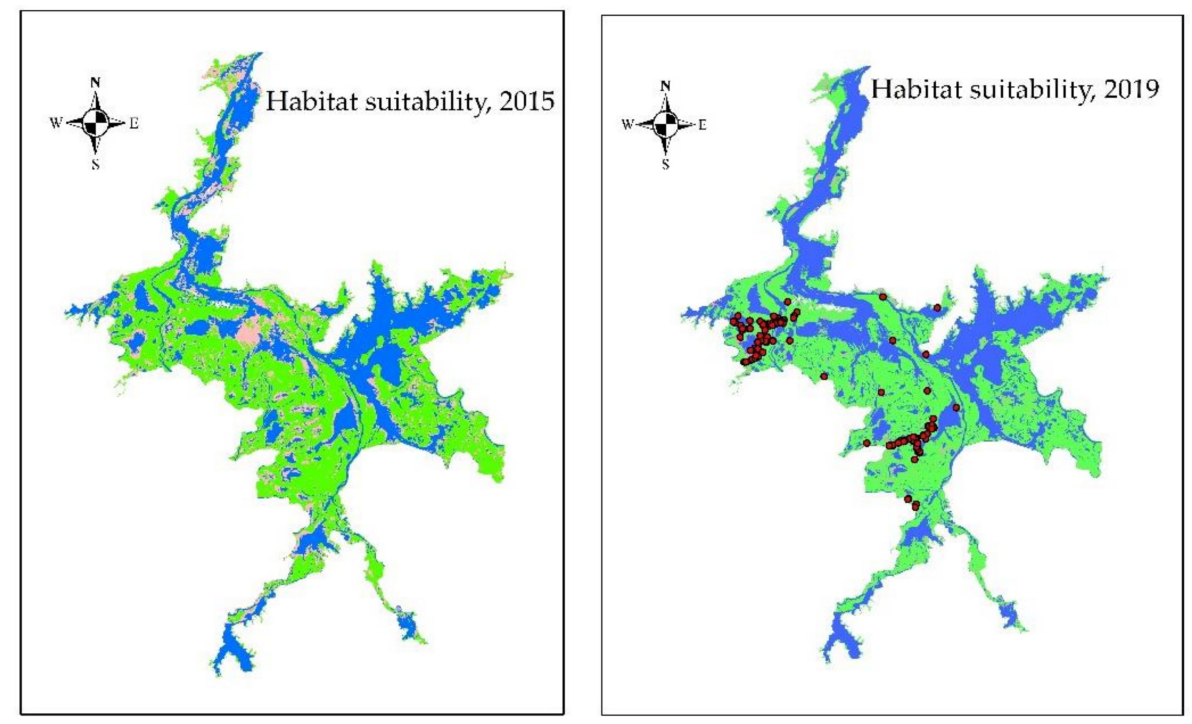

\section{Legend}

$$
\text { Unsuitable } \ \text { Fair } \bigsqcup \text { Good } \quad \text { Best • Validation points }
$$

Figure 7. The habitat suitability map of Herbivorous Anseriformes for the 2015 and 2019 winter seasons of the study area.

Table 3. Habitat suitability grade areas change of Herbivorous Anseriformes during winter seasons of 2015 to 2019.

\begin{tabular}{ccccccc}
\hline Scheme 2015 & $\mathbf{2 0 1 5}$ & $\mathbf{2 0 1 9}$ & $\boldsymbol{\Delta}$ & $\mathbf{2 0 1 5} \%$ & $\mathbf{2 0 1 9} \%$ & $\mathbf{\Delta} \mathbf{0}$ \\
\hline Unsuitable & 12.57 & 15.18 & 2.61 & 0.38 & 0.46 & 0.15 \\
Fair & 1119.57 & 1354.20 & 234.63 & 33.75 & 40.77 & 10.08 \\
Good & 594.89 & 99.30 & -495.59 & 17.93 & 2.99 & -12.59 \\
Best (Suitable) & 1589.99 & 1852.85 & 262.86 & 47.93 & 55.78 & 2.36 \\
\hline
\end{tabular}

\subsection{Habitat Suitability Change from 2015 to 2019}

MULUSCE of QGIS software 2.01 was used to calculate the suitable herbivorous Anseriformes' habitats change in 2015 and 2019 of the study periods. The results showed a slight change in habitat suitability areas (Figure 8 ). The overall habitat suitability changes from 2015 to 2019 are presented in Table 3. The best (suitable) grade area increased from $47.93 \%$ to 55.78 of the study area. Meanwhile, the good grade area decreased from $17.93 \%$ 
to $2.99 \%$ of the study area. The transition matrix shows that only $23 \%$ of good grade areas remained unchanged, and the highest portion was changed to fair grade areas $(58 \%)$ (Table 4).

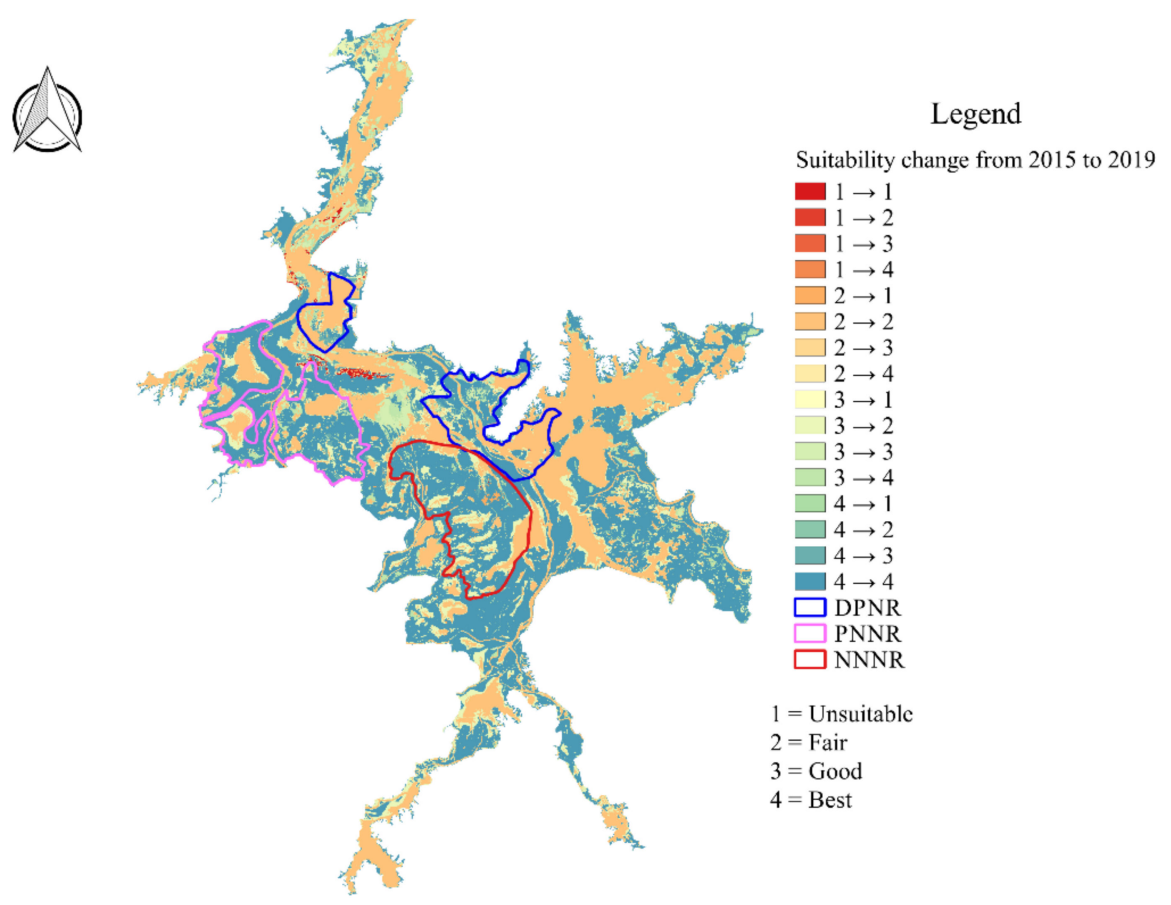

Figure 8. Habitat suitability change of Herbivorous Anseriformes during winter seasons of 2015 to 2019 .

Table 4. Transition matrix.

\begin{tabular}{ccccc}
\hline Suitability Grade & Unsuitable & Fair & Good & Best (Suitable) \\
\hline Unsuitable & 0.84 & 0.16 & 0.000 & 0.00 \\
Fair & 0.01 & 0.99 & 0.002 & 0.00 \\
Good & 0.00 & 0.58 & 0.187 & 0.23 \\
Best (Suitable) & 0.00 & 0.00 & 0.040 & 0.96 \\
\hline
\end{tabular}

\section{Discussions}

This study assessed the habitat suitability of herbivorous Anseriformes wintering in Poyang Lake using geographical information system tools and Landsat images.

Many studies used water resource distance, NDVI, land cover type, and water depth as environment indicators to assess habitat suitability for migratory birds [81,82]. Similarly, in this study, the ecological indicators that determine Anseriformes' lives were identified using habitat suitability analysis. To assess the habitat suitability of wildlife, including birds, it is crucial to consider anthropogenic activity, which plays a great role in wildlife survival. Many studies have used roads' density as environmental disturbance factors while studying habitat suitability assessments [83]. However, in this study, roads do not seriously disturb herbivorous Anseriformes in our study area because they are typically found in/near lakes surrounded by swampland/mudflats, which serve as barriers to protect them from most communities. Therefore, for this study, land cover, NDVI, NDMI, and slope were chosen as the most indicators for assessing herbivorous Anseriformes habitat suitability in this study area. These indicators are the important parameters that help to study a quantitative way of migratory bird suitability status [38,52].

Land cover types (water body, vegetation, mudflat, and sand) were extracted from Landsat 8 OLI, consistent with this area's previous study [53]. However, due to the inundation and hydrological fluctuation, the land cover types differed from time to time. 
The extracted land cover classification accuracy was assessed through our knowledge of the study area and the high-resolution images available in Google Earth Pro. The producer, user, overall accuracy, and Kappa coefficient were used to evaluate the classification results $[71,72]$. The results show that the overall accuracy of land cover classification of 2015 and 2019 in this study reached $96.27 \%$ and $97.58 \%$, and the Kappa values were 93.31 and $96 \%$, respectively, which are satisfactorily acceptable for the research needs (Above $85 \%$ ). The higher the Kappa value, the better the classification accuracy [84].

The NDMI, and NDVI indices were obtained from Landsat 8 image. In Figure 4, the blue regions show higher NDMI and lower/no vegetation growth, which implies higher water availability. Figure 5 shows the spatial distribution of the NDVI, and the green regions generally indicate higher NDVI and better vegetation growth, which implies better food availability for herbivorous Anseriformes.

The habitat suitability map obtained in this result was graded into best, good, fair, and poor (unsuitable) and presented in Figure 6. The study showed the distribution of the habitat suitability for each grade shows significant spatial differences (Figure 6). Vegetations were the areas with the best habitat grade, followed by mudflats (3\%), and these areas cover (55.78\%) the majority of Poyang Lake. The poor and unsuitable grades sites mainly existed in the northern mountainous areas of the Poyang Lake and these area covers small portion the areas $(0.48 \%)$ of the Lake. Nevertheless, due to the environmental indicator's differences, this area's habitat-suitability might not be constant from year to year. This study showed the suitable herbivorous Anseriformes' habitats showed a slight change in habitat suitability areas. For instance, the best (suitable) grade area increased, whereas good grade area decreased. The transition matrix (Table 4 ) shows only $23 \%$ of good grade areas remained unchanged, and the highest portion was changed to fair grade $(58 \%)$. This habitat suitability change could be associated with differences in the area's hydrological fluctuation $[85,86]$.

Therefore, the present study's findings highlight that Poyang Lake has a valuable importance for the conservation of herbivorous Anseriformes. However, more study is needed to identify aquaculture and boats' effect (Pleasure boats and higher boats for transporting goods across the country) in this area. Similarly, the present study's findings highlight that Poyang Lake has huge importance for the conserving wintering aquatic bird species.

This study is limited to the winter seasons of 2015 and 2019 and to limited areas. Extending the years of study and including some ecological variables from different stopovers such as population dynamics and navigation route factors of herbivorous Anseriformes could improve the results.

Supplementary Materials: The following are available online at https:/ /www.mdpi.com/article/10 .3390/d13040171/s1, Figure S1: NDVI time series (2015-2017) derived from MODIS imagery obtained from Google Earth Engine, Table S1: Three major vegetation types of Poyang Lake according to Wan et al. (2018) [64], Table S2: Details of the Landsat 8 image data used which were downloaded from USGS, Table S3: The criteria weights for herbivorous Anseriformes habitat suitability determined using an AHP methods.

Author Contributions: Conceptualization, Q.W. and M.T.D.; methodology, M.T.D., and Q.W.; software, M.T.D.; validation, Q.W., O.O., and M.T.D.; formal analysis, M.T.D.; investigation, M.T.D., Q.W., Z.L., X.S. and Y.L.; resources, M.T.D. and Q.W.; data curation, Q.W., and M.T.D.; writing: original draft, M.T.D.; writing: review and editing, Q.W. and X.S.; visualization, M.T.D.; supervision, Q.W.; project administration, Q.W.; funding acquisition, Q.W. All authors have read and agreed to the published version of the manuscript.

Funding: This research was supported by the National Natural Science Foundation of China (Grant number, 31401978), the Fundamental Research Funds for the Central Universities (Grant number, 2572019BE04), and the Academic and Technical Leader Training Program of Jiangxi Province (Grant number, 20153BCB22007).

Institutional Review Board Statement: Not applicable. 
Informed Consent Statement: Not applicable.

Data Availability Statement: Not applicable.

Acknowledgments: This research was supported by the National Natural Science Foundation of China, the Fundamental Research Funds for the Central Universities, and the Academic and Technical Leader Training Program of Jiangxi Province.

Conflicts of Interest: The authors declare no conflict of interest.

\section{References}

1. Karr, J.R. Seasonality, Resource Availability, and Community Diversity in Tropical Bird Communities. Am. Nat. 2002, 110, 973-994. [CrossRef]

2. $\quad$ Bennett, P.M.; Owens, I.P.; Storch, D.; Thomas, G.H.; Orme, C.D.L.; Rasmussen, P.C.; Gaston, K.J.; Ding, T.-S.; Blackburn, T.M.; Olson, V.A.; et al. Topography, Energy and the Global Distribution of Bird Species Richness. Proc. R. Soc. B Biol. Sci. 2007, 274, 1189-1197.

3. Veech, J.A.; Crist, T.O. Habitat and Climate Heterogeneity Maintain Beta-Diversity of Birds among Landscapes within Ecoregions. Glob. Ecol. Biogeogr. 2007, 16, 650-656. [CrossRef]

4. Karr, J.R.; Roth, R.R. Vegetation Structure and Avian Diversity in Several New World Areas. Am. Nat. 2002, 105, $423-435$. [CrossRef]

5. Gaston, K.J.; Blackburn, T.I.M.M.; Greenwood, J.D.; Gregory, R.D.; Quinn, M.; Lawton, J.H. Abundance-Occupancy Relationships. J. Appl. Ecol. 2000, 37, 39-59. [CrossRef]

6. Venail, P.; Narwani, A.; Naeem, S.; Loreau, M.; Daily, G.C.; Duffy, J.E.; Perrings, C.; Hooper, D.U.; Wardle, D.A.; Larigauderie, A.; et al. Biodiversity Loss and Its Impact on Humanity. Nature 2012, 486, 59-67. [CrossRef]

7. Riemann, J.C.; Ndriantsoa, S.H.; Rödel, M.O.; Glos, J. Functional Diversity in a Fragmented Landscape-Habitat Alterations Affect Functional Trait Composition of Frog Assemblages in Madagascar. Glob. Ecol. Conserv. 2017, 10, 173-183. [CrossRef]

8. Syroechkovskiy , E.E., Jr. Long-Term Declines in Arctic Goose Populations in Eastern Asia. Waterbirds Around World 2006, 649-662.

9. Chen, Y.; Dong, J.; Xiao, X.; Zhang, M.; Tian, B.; Zhou, Y.; Li, B. Land Claim and Loss of Tidal Flats in the Yangtze Estuary. Nat. Publ. Gr. 2016, 1-10. [CrossRef]

10. Mitsch, W.J.; Gosselink, J.G. Wetlands, 5th ed.; Wiley: Hoboken, NJ, USA, 2015.

11. Page, G.W.; Gill, R.E., Jr. Shorebirds in western North America late 1800s to late 1900s. Avian Biol. 1994, 15, 147-160.

12. Zhang, Y.; Wang, Z.; Ren, C.; Yu, H.; Dong, Z.; Mao, D. Changes in Habitat Suitability for Waterbirds of the Momoge Nature Reserve of China during 1990-2014. J. Environ. Eng. Landsc. Manag. 2017, 25, 367-378. [CrossRef]

13. Regmi, G.R.; Huettmann, F. (Eds.) Hindu Kush-Himalaya Watersheds Downhill: Landscape Ecology and Conservation Perspectives; Springer: Cham, Switzerland, 2020. [CrossRef]

14. Bolduc, F.; Afton, A.D. Relationships between Wintering Waterbirds and Invertebrates, Sediments and Hydrology of Coastal Marsh Ponds. Waterbirds 2004, 27, 333-341. [CrossRef]

15. De Boer, W.F.; Cao, L.; Barter, M.; Wang, X.; Sun, M.; Van Oeveren, H.; De Leeuw, J.; Barzen, J.; Prins, H.H.T. Comparing the Community Composition of European and Eastern Chinese Waterbirds and the Influence of Human Factors on the China Waterbird Community. Ambio 2011, 40, 68-77. [CrossRef]

16. Mitsch, W.J.; Gosselink, J.G. Wetlands, 4th ed.; Wiley: Hoboken, NJ, USA, 2007.

17. Rees, E.C.; Bruce, J.H.; White, G.T. Factors Affecting the Behavioural Responses of Whooper Swans (Cygnus c. Cygnus) to Various Human Activities. Biol. Conserv. 2005, 121, 369-382. [CrossRef]

18. Beale, C.M.; Monaghan, P. Behavioural Responses to Human Disturbance: A Matter of Choice? Anim. Behav. 2004, 1065-1069. [CrossRef]

19. Thiollay, J.-M. Raptor communities in French Guiana: Distribution, Habitat selection, and conservation. J. Raptor Res. 2007, 41, 90-105. [CrossRef]

20. Nunez, J.P.; Verdu, J.R.; Galante, E.; Garcia, D.J.; Oropeza, G.O. Birds and Fish as Bioindicators of Tourist Disturbance in Springs in Semi-Arid Regions in Mexico: A Basis for Management. Anim. Biodivers. Conserv. 2007, 30, $29-41$.

21. De Boer, W.F. The Shorebird Community Structure at an Intertidal Mudflat in Southern. Ardea Wageningen 2002, 90, 81-92.

22. Palomino, D.; Carrascal, L.M. Habitat Associations of a Raptor Community in a Mosaic Landscape of Central Spain under Urban Development. Landsc. Urban Plan. 2007, 83, 268-274. [CrossRef]

23. Hackett, S.J.; Kimball, R.T.; Reddy, S.; Bowie, R.C.K.; Braun, E.L.; Braun, M.J.; Chojnowski, J.L.; Cox, W.A.; Han, K.L.; Harshman, J.; et al. A Phylogenomic Study of Birds Reveals Their Evolutionary History. Science 2008, 320, 1763-1768. [CrossRef]

24. Kraan, C.; Van Gils, J.A.; Spaans, B.; Dekinga, A.; Bijleveld, A.I.; Van Roomen, M.; Kleefstra, R.; Piersma, T. Landscape-Scale Experiment Demonstrates That Wadden Sea Intertidal Flats Are Used to Capacity by Molluscivore Migrant Shorebirds. J. Anim. Ecol. 2009, 78, 1259-1268. [CrossRef]

25. Burton, N.H.K.; Rehfisch, M.M.; Clark, N.A.; Dodd, S.G. Impacts of Sudden Winter Habitat Loss on the Body Condition and Survival of Redshank Tringa Totanus. J. Appl. Ecol. 2006, 43, 464-473. [CrossRef]

26. Roloff, G.J.; Kernohan, B.J. Evaluating Reliability of Habitat Suitability Index Models. Wildl. Soc. Bull. 1999, $27,973-985$. 
27. Store, R.; Kangas, J. Integrating Spatial Multi-Criteria Evaluation and Expert Knowledge for GIS-Based Habitat Suitability Modelling. Landsc. Urban Plan. 2001, 55, 79-93. [CrossRef]

28. Brooks, R.P. Improving Habitat Suitability Index Models. Wildl. Soc. Bull. 1997, 25, 163-167.

29. U.S. Fish and Wildlife Service. Standards for the Development of Habitat Suitability Index Models 103 ESM-Ecological Services Manual; U.S. Fish and Wildlife Service: Washington, DC, USA, 1981; p. 171.

30. Kumar, S.; Stohlgren, T.J. Maxent Modeling for Predicting Suitable Habitat for Threatened and Endangered Tree Canacomyrica Monticola in New Caledonia. J. Ecol. Nat. Environ. 2018, 154, 94-98.

31. Thuiller, W.; Araújo, M.B.; Hirzel, A.H.; Brotons, L. Presence-Absence versus Presence-Only Modelling Methods for Predicting Bird Habitat Suitability. Ecography 2004, 27, 437-448.

32. Strubbe, D.; Matthysen, E. Patterns of Niche Conservatism among Non-Native Birds in Europe Are Dependent on Introduction History and Selection of Variables. Biol. Invasions 2014, 16, 759-764. [CrossRef]

33. Zhao, M.; Cong, P.; Barter, M.; Fox, A.D.; Cao, L. The Changing Abundance and Distribution of Greater White-Fronted Geese Anser Albifrons in the Yangtze River Floodplain: Impacts of Recent Hydrological Changes. Bird Conserv. Int. 2012, 22, 135-143. [CrossRef]

34. De Cáceres, M.; Moncunill, J.; Bota, G.; Casas, F.; Giralt, D.; Brotons, L.; Mougeot, F.; Cardador, L.; Arroyo, B.; Butler, S.J.; et al. A Resource-Based Modelling Framework to Assess Habitat Suitability for Steppe Birds in Semiarid Mediterranean Agricultural Systems. PLoS ONE 2014, 9, e92790. [CrossRef]

35. Yao, S.; Li, X.; Liu, C.; Zhang, J.; Li, Y.; Gan, T.; Liu, B. New Assessment Indicator of Habitat Suitability for Migratory Bird in Wetland Based on Hydrodynamic Model and Vegetation Growth Threshold. Ecol. Indic. 2020, 117, 106556. [CrossRef]

36. Reza, M.I.H.; Abdullah, S.A.; Nor, S.B.M.; Ismail, M.H. Integrating GIS and Expert Judgment in a Multi-Criteria Analysis to Map and Develop a Habitat Suitability Index: A Case Study of Large Mammals on the Malayan Peninsula. Ecol. Indic. 2013, 34, 149-158. [CrossRef]

37. Coppes, J.; Nopp-Mayr, U.; Braunisch, V.; Grünschachner-Berger, V.; Storch, I.; Suchant, R. Habitat Suitability Modulates the Response of Wildlife to Human Recreation. Biol. Conserv. 2018, 227, 56-64. [CrossRef]

38. Wu, H.; Dai, J.; Sun, S.; Du, C.; Long, Y. Responses of Habitat Suitability for Migratory Birds to Increased Water Level during Middle of Dry Season in the Two Largest Freshwater Lake Wetlands of China. Ecol. Indic. 2021, 121, 107065. [CrossRef]

39. Fielding, A.H.; Bell, J.F. A Review of Methods for the Assessment of Prediction Errors in Conservation Presence/Absence Models. Environ. Conserv. 1997, 24, 38-49. [CrossRef]

40. Kerr, J.T.; Ostrovsky, M. From Space to Species: Ecological Applications for Remote Sensing. Trends Ecol. Evol. 2003, 18, 299-305. [CrossRef]

41. Bradley, B.A.; Olsson, A.D.; Wang, O.; Dickson, B.G.; Pelech, L.; Sesnie, S.E.; Zachmann, L.J. Species Detection vs. Habitat Suitability: Are We Biasing Habitat Suitability Models with Remotely Sensed Data? Ecol. Modell. 2012, 244, 57-64. [CrossRef]

42. Tang, Z.; Fang, J.; Sun, J.; Gaston, K.J. Effectiveness of Protected Areas in Maintaining Plant Production. PLoS ONE 2011, 6, e19116. [CrossRef]

43. Hirzel, A.H.; Helfer, V.; Metral, F. Assessing Habitat-Suitability Models with a Virtual Species. Ecol. Model. 2001, 145, 111-121. [CrossRef]

44. Shankman, D.; Keim, B.D.; Song, J. Flood Frequency in China's Poyang Lake Region: Trends and Teleconnections. Int. J. Climatol. 2006, 26, 1255-1266. [CrossRef]

45. Ji, W.; Zeng, N.; Wang, Y.; Gong, P.; Xu, B.; Bao, S. Analysis on the Waterbirds Community Survey of Poyang Lake in Winter. Geogr. Inf. Sci. 2007, 13, 51-64. [CrossRef]

46. Wang, Y.; Jia, Y.; Guan, L.; Lu, C.; Lei, G.; Wen, L.; Liu, G. Optimising Hydrological Conditions to Sustain Wintering Waterbird Populations in Poyang Lake National Natural Reserve: Implications for Dam Operations. Freshw. Biol. 2013, 58, $2366-2379$. [CrossRef]

47. Chen, X.; Zong, Y.; Zhang, E.; Xu, J.; Li, S. Human Impacts on the Changiiang (Yangtze) River Basin, China, with Special Reference to the Impacts on the Dry Season Water Discharges into the Sea. Geomorphology 2001, 41, 111-123. [CrossRef]

48. Barzen, J.; Engels, M.; Burnham, J.; Harris, J.; Wu, G. Potential Impacts of a Water Control Structure on the Abundance and Distribution of Wintering Waterbirds at Poyang Lake, Poyang Lake Assessment; International Crane Foundation: Baraboo, WI, USA, 2009; pp. 2-54.

49. Nakayama, T.; Watanabe, M. Role of Flood Storage Ability of Lakes in the Changjiang River Catchment. Glob. Planet. Chang. 2008, 63, 9-22. [CrossRef]

50. Guo, H.; Hu, Q.; Jiang, T. Annual and Seasonal Streamflow Responses to Climate and Land-Cover Changes in the Poyang Lake Basin, China. J. Hydrol. 2008, 355, 106-122. [CrossRef]

51. Xia, S.; Yu, X.; Fan, N. The Wintering Habitats of Migrant Birds and Their Relationship with Water Level in Poyang Lake, China. Resour. Sci. 2010, 32, 2072-2078.

52. Teng, J.; Xia, S.; Liu, Y.; Yu, X.; Duan, H.; Xiao, H. Assessing Habitat Suitability for Wintering Geese by Using Normalized Difference Water Index (NDWI) in a Large Floodplain Wetland, China. Ecol. Indic. 2021, 122, 107260. [CrossRef]

53. Dronova, I.; Gong, P.; Wang, L. Object-Based Analysis and Change Detection of Major Wetland Cover Types and Their Classification Uncertainty during the Low Water Period at Poyang Lake, China. Remote Sens. Environ. 2011, 115, $3220-3236$. [CrossRef] 
54. Kingsford, R.T.; Jenkins, K.M.; Porter, J.L. Imposed Hydrological Stability on Lakes in Arid Australia and Effects on Waterbirds. Ecology 2004, 85, 2478-2492. [CrossRef]

55. Bellio, M.G.; Kingsford, R.T.; Kotagama, S.W. Natural versus Artificial- Wetlands and Their Waterbirds in Sri Lanka. Biol. Conserv. 2009, 142, 3076-3085. [CrossRef]

56. Tamisier, A.; Grillas, P. A Review of Habitat Changes in the Camargue: An Assessment of the Effects of the Loss of Biological Diversity on the Wintering Waterfowl Community. Biol. Conserv. 1994, 70, 39-47. [CrossRef]

57. Liu, D.; Ren, C.; Tang, X.; Liu, C.; Dong, Z.; Jia, M.; Li, L.; Wang, Z. Assessment of Habitat Suitability for Waterbirds in the West Songnen Plain, China, Using Remote Sensing and GIS. Ecol. Eng. 2013, 55, 94-100. [CrossRef]

58. Heinänen, S.; Von Numers, M. Modelling Species Distribution in Complex Environments: An Evaluation of Predictive Ability and Reliability in Five Shorebird Species. Divers. Distrib. 2009, 266-279. [CrossRef]

59. Bock, M.; Xofis, P.; Mitchley, J.; Rossner, G.; Wissen, M. Object-Oriented Methods for Habitat Mapping at Multiple Scales-Case Studies from Northern Germany and Wye Downs, UK. J. Nat. Conserv. 2005, 13, 75-89. [CrossRef]

60. Tian, B.; Zhou, Y.; Zhang, L.; Yuan, L. Analyzing the Habitat Suitability for Migratory Birds at the Chongming Dongtan Nature Reserve in Shanghai, China. Estuar. Coast. Shelf Sci. 2008, 80, 296-302. [CrossRef]

61. Debela, M.T.; Wu, Q.; Chen, L.; Sun, X.; Xu, Z.; Li, Z. Composition and Diversity of Over-Wintering Aquatic Bird Community on Poyang Lake, China. Diversity 2020, 12, 308. [CrossRef]

62. Barter, M.; Cao, L.; Chen, L.; Lei, G. Results of a Survey for Waterbirds in the Lower Yangtze Floodplain, China, in JanuaryFebruary 2004. Forktail 2005, 21, 1-7.

63. Harris, I.; Osborn, T.J.; Jones, P.; Lister, D. Version 4 of the CRU TS Monthly High-Resolution Gridded Multivariate Climate Dataset. Sci. Data 2020, 7, 1-18. [CrossRef]

64. Wan, R.; Dai, X.; Shankman, D. Vegetation Response to Hydrological Changes in Poyang Lake, China. Wetlands 2018, 2, 1-14 [CrossRef]

65. Zhang, L.; Yin, J.; Jiang, Y.; Wang, H. Relationship between the Hydrological Conditions and the Distribution of Vegetation Communities within the Poyang Lake National Nature Reserve, China. Ecol. Inform. 2012, 11, 65-75. [CrossRef]

66. Li, C.; Li, H.; Zhang, Y.; Zha, D.; Zhao, B.; Yang, S.; Zhang, B. Predicting Hydrological Impacts of the Yangtze-to-Huaihe Water Diversion Project on Habitat Availability for Wintering Waterbirds at Caizi Lake. J. Environ. Manag. 2019, 249, 109251. [CrossRef] [PubMed]

67. Yuan, S.; Yang, Z.; Liu, X.; Wang, H. Water Level Requirements of a Carex Hygrophyte in Yangtze Fl Oodplain Lakes. Ecol. Eng. 2019, 129, 29-37. [CrossRef]

68. Xia, S.; Liu, Y.; Chen, B.; Jia, Y.; Zhang, H.; Liu, G.; Yu, X. Effect of Water Level Fluctuations on Wintering Goose Abundance in Poyang Lake Wetlands of China. Chinese Geogr. Sci. 2017, 27, 248-258. [CrossRef]

69. ENVI. ENVI Atmospheric Correction Module: QUAC and FLAASH User's Guide, Version 4.7; ENVI: Boulder, CO, USA, 2009 ; p. 44.

70. Nagendra, H. Biodiversity Assessment at Multiple Scales: Linking Remotely Sensed Data with Field Information Biodiversity Assessment at Multiple Scales: Linking Remotely Sensed Data with Field Information. Proc. Natl. Acad. Sci. USA 1999, 10-15. [CrossRef]

71. Lu, D.; Moran, E.; Batistella, M. Linear Mixture Model Applied to Amazonian Vegetation Classification. Remote Sens. Environ. 2003, 87, 456-469. [CrossRef]

72. Manandhar, R.; Odehi, I.O.A.; Ancevt, T. Improving the Accuracy of Land Use and Land Cover Classification of Landsat Data Using Post-Classification Enhancement. Remote Sens. 2009, 1, 330-344. [CrossRef]

73. McFeeters, S.K. The Use of the Normalized Difference Water Index (NDWI) in the Delineation of Open Water Features. Int. J. Remote Sens. 1996, 17, 1425-1432. [CrossRef]

74. Gorelick, N.; Hancher, M.; Dixon, M.; Ilyushchenko, S.; Thau, D.; Moore, R. Remote Sensing of Environment Google Earth Engine: Planetary-scale Geospatial Analysis for Everyone. Remote Sens. Environ. 2017. [CrossRef]

75. Saaty, T.L. A Scaling Method for Priorities in Hierarchical Structures. J. Math. Psychol. 1977, 15, 234-281. [CrossRef]

76. Saaty, T.L. Response to Holder's Comments on the Analytic Hierarchy Process Thomas. J. Oper. Res. Soc. 1991, 42, 909-914. [CrossRef]

77. Eastman, J.R.; Weigen, J.; Kyem, P.A.K.; Toledano, J. Raster Procedures for Multi-Criteria/Multi-Objective Decisions. Photogramm. Eng. Remote Sens. 1995, 61, 539-547.

78. Goepel, K.D. Implementation of an Online Software Tool for the Analytic Hierarchy Process-Challenges and Practical Experiences. Int. J. Anal. Hierarchy Process 2017, 1-20. [CrossRef]

79. Jung, M. LecoS-A Python Plugin for Automated Landscape Ecology Analysis. Ecol. Inform. 2016, 31, 18-21. [CrossRef]

80. Carver, S. Integrating Multi-Criteria Evaluation with Geographical Information Systems. Int. J. Geogr. Inf. 2015, 5, 321-339. [CrossRef]

81. Zhang, Y.; Fox, A.D.; Cao, L.; Jia, Q.; Lu, C.; Prins, H.H.T.; de Boer, W.F. Effects of Ecological and Anthropogenic Factors on Waterbird Abundance at a Ramsar Site in the Yangtze River Floodplain. Ambio 2018, 1-11. [CrossRef]

82. Ye, X.; Zhang, Q.; Bai, L.; Hu, Q. A Modeling Study of Catchment Discharge to Poyang Lake under Future Climate in China. Quat. Int. 2011, 244, 221-229. [CrossRef]

83. Tang, X.; Li, H.; Xu, X.; Yang, G.; Liu, G.; Li, X.; Chen, D. Changing Land Use and Its Impact on the Habitat Suitability for Wintering Anseriformes in China's Poyang Lake Region. Sci. Total Environ. 2016, 557-558, 296-306. [CrossRef] 
84. Foody, G. Book Review: Classification Methods for Remotely Sensed Data. Prog. Phys. Geogr. Earth Environ. 2003, 27. [CrossRef]

85. Wang, L.; Dronova, I.; Gong, P.; Yang, W.; Li, Y.; Liu, Q. A New Time Series Vegetation-Water Index of Phenological-Hydrological Trait across Species and Functional Types for Poyang Lake Wetland Ecosystem. Remote Sens. Environ. 2012, 125, 49-63. [CrossRef]

86. Wang, Z.; Li, C.; Yang, Z.; Yang, L.; Zhang, D.; Zhou, L. The Relationship between Seasonal Water Level Fluctuation and Habitat Availability for Wintering Waterbirds at Shengjin Lake, China. Bird Conserv. Int. 2018, 1-15. [CrossRef] 